\title{
Quantification and simulation of soil water on grazed fescue watersheds
}

\author{
DAVID S. CHANASYK, EMMANUEL MAPFUMO, WALTER D. WILLMS, AND M. ANNE NAETH
}

Authors are Professors and Post-doctoral Research Associate in Department of Renewable Resources, University of Alberta, Edmonton, Alberta, Canada T6G 2HI, Research Scientist Lethbridge Research Centre, Agriculture and Agri-Food Canada, P.O. Box 3000 Lethbridge, Alberta, Canada TIJ 4BI.

\section{Abstract}

A 2-year study was conducted at the Agriculture and AgriFood Canada Stavely Range Substation, Alberta. The objective was to quantify and simulate the soil water status of small grassland watersheds under 3 grazing intensities and 4 topographic positions. The grazing treatments were ungrazed (or control), heavy (2.4 $\left.\mathrm{AUM} \mathrm{ha}^{-1}\right)$ and very heavy (4.8 $\left.\mathrm{AUM} \mathrm{ha}^{-1}\right)$ grazing and the topographic positions were upperslope, midslope, lowerslope and $5 \mathrm{~m}$ away from the collector drain. Moisture readings were taken every 2 weeks between spring and fall using a CPN 503 moisture neutron probe. Readings were taken at the soil surface and at 15-, 25-, 35-, 45- and 55-cm depths. Total annual precipitation in 1998 and 1999 was 648 and 399 mm, respectively. In both years grazing treatments did not affect total soil water in the 0-50 cm (TSW50) depth interval for the upper, middle and lower slope positions, but TSW50 close to the collector drain was significantly $(\mathrm{P} \leq \mathbf{0 . 0 5})$ greater for the heavy grazed compared to the very heavy grazed treatment. Within each grazing treatment, TSW50 differences among slope positions occurred mainly under the heavy grazed treatment. Simulation of soil water at each soil depth and watershed was conducted using the Versatile Soil Moisture Budget Model (VB2000). Statistical and graphical evaluations of the model results were conducted using the volumetric soil water data collected for 1998 and 1999. The statistics determined included average error (AE), root mean square (RMS), coefficient of residual mass (CRM), modeling efficiency (EF) and coefficient of determination (CD). All statistics varied with each soil depth and watershed, indicating the transient nature of the data. This is reflected in the mostly negative CRM values, which ranged between -1.0 and 0.16 . Overall model fitting to the whole data for all depths, watersheds and years gave values of CRM = -0.08 and $\mathbf{E F}=0.19$, indicating a slight over-prediction by the model. Spatial variation due to presence of rocks or cracks and averaging across slopes may have partly contributed to the discrepancies between model results and observed data.

Key Words: grazing, model performance, moisture budget

The impetus to better understand the hydrologic processes of managed ecosystems stems from our concern about agricultural practices that potentially create adverse effects on the soil and the surrounding environment, such as surface runoff and erosion. The

We gratefully acknowledge funding received from the Alberta Agricultural Research Institute and the Natural Sciences and Engineering Research Council. Thanks to Brian Henderek and Kelly Ostermann for assistance with field work and data collection.

Manuscript accepted 23 May 03.

\section{Resumen}

Se condujo un estudio de 2-años en la Subestación Stavley de Pastizales perteneciente a Agriculture and Agri-Food Canada Stavely Range localizada en Alberta, Canada. El objetivo fue cuantificar y simular el estado del agua en el suelo de pequeñas cuencas hidrológicas de pastizal bajo 3 intensidades de apacentamiento y 4 posiciones topográficas. Los tratamientos de apacentamiento evaluados fueron: sin apacentamiento (control), apacentamiento fuerte $\left(2.4 \mathrm{AUM} \mathrm{ha-}^{-1}\right) \mathrm{y}$ apacentamiento muy fuerte (4.8 $\mathrm{AUM} \mathrm{ha}^{-1}$ ) y las posiciones topográficas: parte alta, media y baja de la pendiente y $5 \mathrm{~m}$ alejado del dren colector. Las lecturas de humedad se tomaron cada dos semanas entre primavera y verano usando un dispersor de neutrones modelo CPN 50 y se tomaron en la superficie del suelo y a 15, 25, 35, 45 y 55 cm de profundidad. La precipitación total anual en 1998 y 1999 fue de 648 y $399 \mathrm{~mm}$ respectivamente. En ambos años los tratamientos de apacentamiento no afectaron el agua total del suelo en el estrato de 0 a $50 \mathrm{~cm}$ (TSW50) de profundidad de las posiciones alta media y baja de la pendiente, pero el TSW50 cercano al dren colector fue significativamente $(P \leq 0.05)$ mayor en el apacentamiento fuerte en comparación con el tratamiento de apacentamiento muy fuerte. Dentro de cada tratamiento de apacentamiento las diferencias de TSW50 entre las posiciones topográficas ocurrieron principalmente bajo el tratamiento de apacentamiento fuerte. La simulación del agua del suelo en cada estrato de profundidad y cuenca hidrológica se condujo usando el Modelo Versátil de Balance de Humedad del Suelo (VB2000). Las evaluaciones estadísticas y gráficas de los resultados del modelo se condujeron usando datos volumétricos del agua del suelo coleçtados en 1998 y 1999. Los estadísticos determinados incluyeron el error promedio (AE) raíz cuadrada de las medias (RMS), el coeficiente de la masa de residuales (CRM), eficiencia del modelaje (EF) y el coeficiente de determinación (CD). Todos los estadísticos variaron en cada profundidad del suelo y cuenca, indicando la naturaleza transitoria de los datos. Esto esta reflejado principalmente en los valores negativos del CRM, los cuales variaron de $-\mathbf{1 . 0}$ a 0.16 . El ajuste general del modelo al juego total de datos para todas las profundidades, cuencas y años da valores de $\mathbf{C R M}=-0.08$ y $\mathbf{E F}=0.19$, indicando una ligera sobrepredicción por el modelo. La variación espacial debida a al presencia de rocas y grietas a través de las pendientes puede haber contribuido parcialmente a las discrepancias entre los resultados del modelo y los datos observados. 
amount and movement of water in the soil greatly influences erosion, nutrient leaching and organic matter decomposition (Brye et al. 2000). Further, the spatial and temporal distribution of soil water is a critical part of many disciplines including agriculture and ecosystem modeling and dramatically affects the key hydrologic process of infiltration.

The dynamics of soil water movement and storage reflects the complex interactions among soil physico-chemical properties, weather, vegetation type and land management practices (Twerdoff et al. 1999). Productivity of rangelands is dependent on natural precipitation as well as the efficiency of soil water storage in the profile. To enable a sustainable agricultural system, grazing management practices must ensure adequate soil water for plant growth. This means monitoring soil water availability is essential for longterm planning and management decisions. Unfortunately difficulties with soil water measurement techniques associated with intensive labor requirements and timeconsuming training have made long-term soil water data sets difficult and expensive to compile (Hymer et al. 2000). For example, gravimetric moisture measurements are simple but destructive and require at least 24 hours of post-processing. On the other hand neutron probes are nondestructive and can sample over great depths, but are expensive and require appropriate training. These problems have led to development of mathematical models for simulating movement of water in the soil-plant-atmosphere system.

A large number of models have been published, and range in complexity from simple water budget models to more comprehensive generic models involving partial differential equations to calculate soil water flow (Elmaloglou and Malamos 2000). A simple water budget model, the Versatile Soil Moisture Budget (VB), was first proposed 35 years ago (Baier and Robertson 1966). The model requires a limited amount of generally available input data. The application of this model in Canada has been widespread and has been used in estimating soil water storage under cultivated semi-arid conditions. The applications of the model have included monitoring soil moisture reserves over large areas, planning farming operations, agroclimatic resource assessment and mapping (Baier and Robertson 1996).

In general, hydrologic research has traditionally focused on arid and semi-arid zones and there is little information about hydrologic parameters for the Canadian prairies. Earlier studies in the foothills of Alberta indicated that soil water below 15 $\mathrm{cm}$ was highest during dry periods in the control and lowest under very heavy grazing (Naeth and Chanasyk 1995). Hydrologic studies in this area revealed that the majority of annual runoff occurred during snowmelt and that few summer storms caused runoff. The runoff generated from snowmelt was decreased with increasing grazing intensity (Naeth and Chanasyk 1996).

The objectives of this study were to quantify soil water from small foothills fescue watersheds under 3 levels of grazing intensity (control, heavy and very heavy) and to evaluate the ability of the VB2000 model to simulate soil water content for the 3 study watersheds.

\section{Model Description}

The Versatile Soil Moisture Budget (VB2000) model describes water movement in the soil in 1 dimension (Baier et al. 2000). The soil profile is divided into several zones, with each zone characterized by a root density, saturation, field capacity and wilting point. The deepest zone is usually considered to end at the maximum rooting depth. The zones are grouped in 1 drainage layer to simulate that all zones were simultaneously drained at the same rate. At the bottom is a second drainage layer (also known as the reservoir) that relates to management of the water table and is limited by the maximum water table depth. This water table function is rarely used in semi-arid conditions where the water table is very deep. The dynamics of soil water movement includes the processes of infiltration, runoff, evapotranspiration, percolation and capillary rise. Soil moisture gain in the profile occurs as a result of input from precipitation or irrigation, whereas loss of water from the profile is via evapotranspiration, runoff, percolation or lateral drainage. Water movement is budgeted for each zone and the drainage layer.

The model input parameters were contained in 2 files, a meteorological data file and a control file. The meteorological input data included daily maximum and minimum temperatures, precipitation and potential evapotranspiration. Potential and actual evapotranspiration were estimated using the Penman-Monteith equation (Monteith 1980), using wind speed, solar radiation and maximum and minimum air temperatures. The control file required input data such as the number of soil lay- ers, depth of each layer, bulk density, water retention properties, depth of water table, beginning of simulation, end of simulation, base temperature and drainage characteristics. The model assumes a tipping-bucket approach to water movement in one dimension, vertically (only after an overlaying layer reaches field capacity will the water move into the next deeper layer). The model also assumes that the use of water in a zone is related to the amount of roots in that zone and utilizes a crop coefficient for that zone to withdraw water from it.

\section{Materials and Methods}

\section{Study Site, Meteorological Conditions and Hydrologic Measurements}

The field study was conducted at the Agriculture and Agri-Food Canada Stavely Range Substation, in the fescue grasslands in the Porcupine Hills (Rocky Mountain foothills) of southwestern Alberta, Canada. The substation is located approximately $100 \mathrm{~km}$ south of Calgary, Alberta (latitude $50^{\circ} \mathrm{N}$ and longitude $114^{\circ}$ W). The site was fenced to create paddocks in 1949. This site is characterized by hilly topography with slopes ranging from $18-37 \%$. Annual average precipitation is $550 \mathrm{~mm}$ with $40 \%$ of it occurring as snow. The most prevalent soils on the site are Typic Haplustolls of loam to clay loam texture. The plant species predominantly on the site included Festuca campestris Rydb. (rough fescue) and Danthonia parryi Scribn. (Parry's oatgrass).

Three watersheds were defined in 1996/97, 1 in each of 2 grazing treatments and an ungrazed control. These watersheds are generally similar in all physiographic characteristics such as size, shape, slope, elevation, orientation and length of overland flow. The 2 grazing treatments were heavy grazing (2.4 AUM ha $\left.{ }^{-1}\right)$ and very heavy grazing (4.8 AUM ha $\left.{ }^{-1}\right)$. Each watershed was approximately rectangular in shape: $100 \mathrm{~m}$ wide and approximately $180-250 \mathrm{~m}$ long. The 2 grazing watersheds were adjacent; the uncontrolled grazed one was located approximately $1 \mathrm{~km}$ to the west of these 2 grazed watersheds. All 3 watersheds faced east and had average slopes of $18-20 \%$. Slopes within each watershed were generally fairly uniform.

The uppermost elevation of the 2 grazed watersheds was $1340 \mathrm{~m}$ whereas that for the ungrazed control was $1351 \mathrm{~m}$. There was only 1 outlet for surface water from all slope positions on each watershed. The 
exit elevation for the 2 grazed watersheds was common and located at $1295 \mathrm{~m}$. The exit elevation for the ungrazed control was $1311 \mathrm{~m}$. A combination of natural and wooden barriers were used to delineate the watersheds and to restrict the water flow from crossing watersheds. A collector drain was utilized in each watershed to take overland flow to a measuring location. Research on the runoff component of this study was reported separately (Chanasyk et al., 2003).

Within each watershed neutron probe access tubes were installed on the upper, middle and lower slope positions (in nests of 3 access tubes approximately $5 \mathrm{~m}$ apart) and also on positions $5 \mathrm{~m}$ from the collector drains (in nests of 5 access tubes across the bottom of the watersheds, approximately $15 \mathrm{~m}$ apart). Access tubes were installed on a given contour as much as possible. The upper slope position was located approximately $20 \mathrm{~m}$ from the crest of the slope in the 2 grazed treatments and approximately $50 \mathrm{~m}$ from it in the ungrazed watershed. The 3 slope positions were located approximately $60 \mathrm{~m}$ apart in the 2 grazed treatments and $40 \mathrm{~m}$ apart in the ungrazed treatment. Due to the topography of the individual watersheds, the lower slope position in the very heavy grazed treatment was located $80 \mathrm{~m}$ from the collector drain position, $40 \mathrm{~m}$ in the heavy grazed treatment and $30 \mathrm{~m}$ in the ungrazed control.

Soil water measurements were taken every 2 weeks in 1998 and 1999 to a 55$\mathrm{cm}$ depth using a CPN 503 soil moisture neutron probe in the access tubes. Moisture readings were first taken at the $15-\mathrm{cm}$ depth and thereafter at $10-\mathrm{cm}$ depth increments. Volumetric moisture content was calculated using a calibration equation obtained for the site. Measurements began as early as possible after snow melt (late March to Mid-April) and ended as late in the fall as possible. Total soil water (TSW) was calculated as depth $(\mathrm{mm})$ by summing incremental soil water measurements to $50 \mathrm{~cm}$. A 2-way analysis of variance was conducted on total soil water data to $50 \mathrm{~cm}$ (TSW50) using the SAS Mixed model procedure with the unstructured variance option (SAS Institute 2000). Mean separation was conducted using the least squares means procedure with the PDIFF option in SAS.

Daily air temperature and precipitation were measured on site from mid-April to mid-November. The daily averages for these 2 parameters were compared with long-term normal (LTN) parameters taken at a station $50 \mathrm{~km}$ away from the study site. A meteorological station was installed at the substation with sensors for measuring temperature, relative humidity, precipitation, wind and radiation variables. Total soil water for the $0-50 \mathrm{~cm}$ interval (TSW50) was compared with soil water at both field capacity and wilting point to determine the frequency of available soil water as well as potential losses due to deep percolation. Soil water contents at field capacity (FC) and at wilting point (WP) to a depth of $50 \mathrm{~cm}$ were determined by Naeth and Chanasyk (1996) to be 155 and $95 \mathrm{~mm}$, respectively at suction values of -33 and $-1500 \mathrm{kPa}$, respectively. Soil water holding capacity (WHC) was calculated as FC - WP.

Frequency of occurrence of a given total soil water level was determined for each watershed and slope treatment combination, by categorizing it into Classes I-VI, using a procedure similar to that used for total soil water data collected in central Alberta (Burk et al. 2000). Class I was defined as TSW50 < wilting point, which represented a very dry soil condition for plant growth. Class II was WP $<$ TSW50 $<(\mathrm{WP}+0.25 \mathrm{WHC})$ and represented a relatively dry moisture condition. Class III was $(\mathrm{WP}+0.25 \mathrm{WHC})<\mathrm{TSW} 50<$ (FC 0.50 WHC), which represented a moist condition for plant growth. Class VI was defined as the total soil water between (FC - 0.50 WHC) $<$ TSW $50<$ (FC - 0.25 WHC). Class V was (FC - 0.25 WHC) $<$ TSW50 < FC, which theoretically represented the most ideal soil water condition for plant growth. Class VI was TSW50 > FC, which represented a wet soil condition and presence of drainage water. Criticisms of the validity of applying laboratorydetermined FC and WP values to field conditions are recognized; these soil hydrologic parameters are merely used as reference marks for soil water level categorization.

\section{Model Input Data}

For the model in this study 5 soil depths were used, each representing the soil depth at which soil water measurements were made (i.e., 15, 25, 35, 45 and $55 \mathrm{~cm}$ ). For the ungrazed watershed these zones had bulk densities of $0.80,1.00,1.16,1.34$ and $1.43 \mathrm{Mg} \mathrm{m}^{-3}$, respectively. For the heavy grazed watershed, these were $0.70,1.00$, $1.30,1.45$ and $1.65 \mathrm{Mg} \mathrm{m}^{-3}$, respectively. For the very heavy grazed watershed the soil bulk densities for the zones were 0.80 , $0.99,1.16,1.40,1.62 \mathrm{Mg} \mathrm{m}^{-3}$, respectively. These values were taken from an adjacent study involving similar grazing treatments (Naeth 1988), and were assumed to be constant throughout the study period. Simulations were conducted separately for each year and grazing treatment. The initial moisture content values used in the simulations were the moisture contents measured on the first measurement date using the neutron probe. Since the water table at the study site was deep (>10 m), we did not include the water table function and we assumed that all 5 zones were treated as a single drainage layer, which drained within 1 day. Percentages of total water uptake from the 5 zones (crop coefficients in the model) were considered to be $25,30,15,15$ and $15 \%$ from the zones of $0-15,15-25,25-35,35-45$ and 45-55 $\mathrm{cm}$ depth increments, respectively. These were considered to be representative of the semi-arid rangelands and were kept constant throughout the growing season. The runoff coefficient was assumed to be $10 \%$, i.e. one tenth of the total precipitation was lost as surface runoff. Given that the model was supposed to function with few input data, attempts were not made to calibrate the model.

\section{Model Evaluation}

Model evaluation was conducted for each watershed using the data collected for the 3 study years and for all soil depths monitored. The quantitative procedures for model evaluation consisted of the use of the statistical analysis to calculate the average error (AE), the root mean square error (RMSE \%), the root mean square (RMS \%), the modeling efficiency (EF), coefficient of determination (CD) and the coefficient of residual mass (CRM) between the measured and simulated soil water values. The equations representing these relationships are as follows (Loague and Green 1991);

$$
A E=\sum_{i=1}^{n}\left(P_{i}-O_{i}\right) / n
$$

$$
\begin{aligned}
& R M S E=100\left(\sum_{i=1}^{n}\left(P_{i}-O_{i}\right)^{2} / n\right)^{1 / 2} / \bar{O} \\
& R M S=100\left(\sum_{i=1}^{n}\left(P_{i}-O_{i}\right)^{2} / n\right)^{1 / 2}
\end{aligned}
$$

$$
E F=\left(\sum_{i=1}^{n}\left(O_{1}-\dot{O}\right)^{2}-\sum_{i=1}^{n}\left(P_{1}-\bar{O}\right)^{2}\right) / \sum_{i=1}^{n}\left(O_{1}-\dot{O}\right)^{2}
$$




$$
C D=\sum_{i=1}^{n}\left(O_{i}-\bar{O}\right)^{2} / \sum_{i=1}^{n}\left(P_{i}-\bar{O}\right)^{2}
$$

$C R M=\left(\sum_{i=1}^{n} O_{i}-\sum_{i=1}^{n} P_{i}\right) / \sum_{i=1}^{n} O_{i}$

where $\mathrm{P}_{\mathrm{i}}$ and $\mathrm{O}_{\mathrm{i}}$ are the predicted and measured values of soil water, respectively and $n$ is the number of soil water values. The optimal values are $0,0,0,1,1$ and 0 for AE, RMSE, RMS, EF, CD and CRM, respectively. Negative values of CRM indicate that the model over-estimates the measured values whereas positive CRM values indicates under-estimation of measured values. If EF is less than 0 , it is better to use the observed mean than to use the model-predicted values.

\section{Results and Discussion}

\section{Grazing and slope impacts on total soil water}

Precipitation between March and November in 1998 was $620 \mathrm{~mm}$ but only $397 \mathrm{~mm}$ in 1999, hence potentially providing a very strong variation in soil water between study years. Precipitation appears to have been well distributed throughout 1998, including October (Table 1). In contrast, precipitation in 1999 was ample between May and August, inclusive, but was very limited in September and October 1999 (Table 1).

Statistical analyses indicated some significant differences among grazing intensities and slope positions. For the upper, middle and lower slope positions, there were no significant differences in total soil water for the $0-50 \mathrm{~cm}$ interval (TSW50) among grazing treatments in 1998 (Table 2). However, close to the collector drain TSW50 was significantly greater ( $\mathrm{P} \leq$ 0.05 ) for the heavy grazed compared with very heavy grazed and ungrazed treatments. Within the very heavy grazed treatment TSW50 was generally similar among slope positions (Table 2). However, for the heavy grazed treatment TSW50 on the majority of measurement dates was significantly greater close to the collector drain compared to the other 3 slope positions. Also for the ungrazed treatment, TSW50 on the majority of measurement dates was similar among all slope positions.

In 1999, some statistical differences in TSW50 among treatments were obtained (Table 3). For the upper, middle and lower slope positions no significant differences in TSW50 among grazing treatments were

Table 1. Cumulative precipitation and average air temperature between measurement periods during 1998 and 1999.

\begin{tabular}{|c|c|c|c|c|c|}
\hline Date & Ppt. & Aver.Temp. & Date & Ppt. & Aver. Temp. \\
\hline & $(\mathrm{mm})$ & ${ }^{\circ} \mathrm{C}$ & & $(\mathrm{mm})$ & ${ }^{\circ} \mathrm{C}$ \\
\hline 16 Apr. 98 & - & - & 24 Mar.99 & - & - \\
\hline 30 Apr. 98 & $66.8^{1}$ & $-2.9^{2}$ & 14 Apr. 99 & $13.3^{1}$ & $1.3^{2}$ \\
\hline 15 May 98 & 13.5 & 10.4 & 27 Apr. 99 & 48.2 & 8.2 \\
\hline 20 May 98 & 5.2 & 12.1 & 04 May 99 & 7.9 & 4.0 \\
\hline 26 May 98 & 32.3 & 8.8 & 13 May 99 & 7.0 & 4.4 \\
\hline 29 May 98 & 83.8 & 12.9 & 28 May 99 & 26.4 & 10.3 \\
\hline 4 Jun. 98 & 44.3 & 9.5 & 04 Jun. 99 & 38.2 & 8.1 \\
\hline 18 Jun. 98 & 13.7 & 10.9 & 11 Jun. 99 & 49.6 & 8.9 \\
\hline 22 Jun. 98 & 123.2 & 13.0 & 18 Jun. 99 & 2.4 & 14.9 \\
\hline 02 Jul. 98 & 9.2 & 13.8 & 23 Jun. 99 & 6.6 & 13.4 \\
\hline 17 Jul. 98 & 82.0 & 17.3 & 02 Jul. 99 & 50.4 & 9.6 \\
\hline 23 Jul. 98 & 70.5 & 17.1 & 13 Jul. 99 & 14.5 & 14.4 \\
\hline 30 Jul. 98 & 1.4 & 20.1 & 21 Jul. 99 & 26.8 & 11.2 \\
\hline 07 Aug. 98 & 24.9 & 19.3 & 12 Aug. 99 & 43.6 & 15.8 \\
\hline 13 Aug. 98 & 0.0 & 20.3 & 18 Aug. 99 & 18.2 & 14.6 \\
\hline 20 Aug. 98 & 9.2 & 15.7 & 25 Aug. 99 & 0.6 & 19.4 \\
\hline 03 Sep. 98 & 2.7 & 18.8 & 01 Sep. 99 & 0.5 & 14.8 \\
\hline 10 Sep. 98 & 0.0 & 16.9 & 08 Sep. 99 & 0.0 & 10.7 \\
\hline 17 Sep. 98 & 6.0 & 16.2 & 22 Sep. 99 & 11.6 & 13.9 \\
\hline 24 Sep. 98 & 6.5 & 10.3 & 29 Sep. 99 & 4.0 & 7.0 \\
\hline 01 Oct. 98 & 12.8 & 9.6 & 06 Oct. 99 & 4.4 & 4.5 \\
\hline 05 Oct. 98 & 0.7 & 7.7 & 14 Oct. 99 & 0.0 & 6.1 \\
\hline 22 Oct. 98 & 11.7 & 7.9 & 20 Oct. 99 & 4.2 & 6.8 \\
\hline 30 Oct. 98 & 0.1 & 8.4 & 28 Oct. 99 & 0.0 & 9.7 \\
\hline \multirow[t]{2}{*}{5 Nov. 98} & 7.5 & 0.4 & 04 Nov. 99 & 0.2 & 3.6 \\
\hline & & & 18 Nov. 99 & 8.6 & 6.9 \\
\hline
\end{tabular}

Cumulative precipitation since the last measurement date

${ }^{2}$ Average daily air temperature since the last measurement date

obtained. However, for the collector drain TSW50 under very heavy grazed treatment was significantly $(\mathrm{P} \leq 0.05)$ lower than that under heavy grazed and ungrazed treatments. Within the very heavy grazed and ungrazed treatments, comparison of TSW50 among slope positions indicated non-significant differences among upper, middle, lower and collector drain positions. However, within the heavy grazed treatment TSW50 close to the collector drain was significantly $(P \leq 0.05)$ greater than that for the other 3 slope positions.

Grazing intensity affected TSW50 patterns throughout the growing season, especially in 1999 (Fig. 1 and 2). In general the grazed treatments had lower TSW50 than the ungrazed treatment, especially for the upper (Fig. 1), middle and lower slope positions. The trends for these latter 2 slope positions were similar to that for the upper slope position and are not shown. The lower TSW50 under grazed treatments may be a result of a combination of reduced infiltration (and hence recharge of the soil profile) and evapotranspiration. Similar findings were reported on smaller, flat areas of these foothills fescue grassland ecosystems (Naeth et al. 1991). In theory, one would expect less soil water in grazed treatments than ungrazed treatments during the early part of growing season due to reduced infiltration resulting from animal trampling, but later in the season the opposite might be expected due to reduced vegetation mass and associated reduced evapotranspiration. However, in this study the TSW50 for grazed treatments was generally lower than that for the ungrazed treatment throughout the growing season.

Slope position had little influence on TSW50 for the very heavy grazed treatment in both years. For heavy grazed and ungrazed treatments, TSW50 close to the collector drain was greater than that for the other slope positions in both 1998 (Fig. 3) and 1999 (data not shown), as expected. However, differences in the soil water patterns among treatments for upper, middle and lower slope positions were not consistent. These results are in partial agreement with the findings of Naeth et al. (1991) who reported lower total soil water for the grazed compared to ungrazed treatments. However, it should be noted that although their results were obtained from the same experimental region, their measurements of total soil water were conducted on relatively flat and smaller areas. 
Table 2. Total soil $(0$ to $50 \mathrm{~cm})$ water $(\mathrm{mm})$ for all watersheds $x$ slopes in 1998.

\begin{tabular}{|c|c|c|c|c|c|c|c|c|c|c|c|c|}
\hline \multirow[t]{2}{*}{ Date } & \multicolumn{4}{|c|}{ Very Heavy Grazed } & \multicolumn{4}{|c|}{ Heavy Grazed } & \multicolumn{4}{|c|}{ Control } \\
\hline & Upper & Mid & Low & Coll. & Upper & Mid & Low & Coll. & Upper & Mid & Low & Coll. \\
\hline 16 Apr. 98 & $161 \mathrm{a}$ & $183 \mathrm{a}$ & 168 a & 190 a & 187 a & 177 a & 190 a & 205 a & 181 a & 187 a & 187 a & 196 a \\
\hline 30 Apr. 98 & $150 \mathrm{~d}$ & $167 \mathrm{~cd}$ & $154 \mathrm{~d}$ & $176 \mathrm{~cd}$ & $178 \mathrm{bcd}$ & $163 \mathrm{~cd}$ & $164 \mathrm{~cd}$ & 202 a & $180 \mathrm{abcd}$ & $184 a b c$ & $182 \mathrm{abc}$ & $197 \mathrm{ab}$ \\
\hline 15 May 98 & $84 \mathrm{e}$ & 99 bcde & 88 de & 100 bcde & $108 \mathrm{bcd}$ & 92 cde & $83 \mathrm{e}$ & $113 \mathrm{abc}$ & $115 \mathrm{abc}$ & $117 \mathrm{ab}$ & $120 \mathrm{ab}$ & $130 \mathrm{a}$ \\
\hline 20 May 98 & $129 \mathrm{~d}$ & $146 \mathrm{~cd}$ & $130 \mathrm{~d}$ & $146 \mathrm{~cd}$ & $156 \mathrm{bc}$ & $128 \mathrm{~d}$ & $129 \mathrm{~d}$ & $167 \mathrm{abc}$ & $172 \mathrm{abc}$ & $174 a b$ & $176 a b$ & $186 \mathrm{a}$ \\
\hline 26 May 98 & $172 b$ & $179 \mathrm{~b}$ & $175 \mathrm{~b}$ & $183 \mathrm{ab}$ & $175 \mathrm{~b}$ & $185 \mathrm{ab}$ & $181 \mathrm{ab}$ & $200 \mathrm{a}$ & $181 \mathrm{ab}$ & $192 \mathrm{ab}$ & $182 \mathrm{ab}$ & $200 \mathrm{a}$ \\
\hline 29 May 98 & $188 \mathrm{~b}$ & $192 \mathrm{~b}$ & $194 \mathrm{~b}$ & $201 \mathrm{ab}$ & $186 \mathrm{~b}$ & $204 a b$ & $198 \mathrm{ab}$ & $205 \mathrm{ab}$ & $195 \mathrm{~b}$ & $204 \mathrm{ab}$ & $197 \mathrm{ab}$ & 215 a \\
\hline 04 Jun. 98 & $171 \mathrm{c}$ & $180 \mathrm{bc}$ & $176 \mathrm{c}$ & $185 \mathrm{abc}$ & $173 \mathrm{c}$ & $188 \mathrm{abc}$ & $185 \mathrm{abc}$ & $205 \mathrm{a}$ & $177 \mathrm{c}$ & $191 \mathrm{abc}$ & $181 \mathrm{bc}$ & $201 \mathrm{ab}$ \\
\hline 18 Jun. 98 & $175 \mathrm{~b}$ & $181 \mathrm{~b}$ & $179 \mathrm{~b}$ & $192 \mathrm{ab}$ & $176 \mathrm{~b}$ & $190 \mathrm{ab}$ & $186 \mathrm{ab}$ & $198 \mathrm{ab}$ & $181 \mathrm{~b}$ & $193 \mathrm{ab}$ & $183 \mathrm{~b}$ & $204 \mathrm{a}$ \\
\hline 22 Jun. 98 & $173 c$ & $181 \mathrm{bc}$ & $178 \mathrm{c}$ & $196 \mathrm{abc}$ & $175 \mathrm{c}$ & $190 \mathrm{abc}$ & $187 \mathrm{bc}$ & $214 \mathrm{a}$ & $180 \mathrm{c}$ & $194 \mathrm{abc}$ & $182 b c$ & $203 a b$ \\
\hline 02 Jul. 98 & $158 \mathrm{c}$ & $162 \mathrm{bc}$ & $163 \mathrm{bc}$ & $163 \mathrm{bc}$ & $160 \mathrm{bc}$ & $173 a b$ & $168 \mathrm{bc}$ & $169 \mathrm{abc}$ & $165 \mathrm{bc}$ & $173 \mathrm{ab}$ & $167 \mathrm{bc}$ & $181 \mathrm{a}$ \\
\hline 17 Jul. 98 & $150 \mathrm{e}$ & 161 bcde & $153 \mathrm{de}$ & $176 b c$ & $153 \mathrm{de}$ & 170 bcde & 166 bcde & $204 \mathrm{a}$ & $155 \mathrm{cde}$ & 174 bcd & 162 bcde & $179 \mathrm{~b}$ \\
\hline 23 Jul. 98 & $127 \mathrm{c}$ & $140 \mathrm{bc}$ & $132 \mathrm{c}$ & $156 \mathrm{~b}$ & $132 \mathrm{c}$ & $150 \mathrm{bc}$ & $139 \mathrm{bc}$ & $194 a$ & $130 \mathrm{c}$ & $151 \mathrm{bc}$ & $140 \mathrm{bc}$ & $156 \mathrm{~b}$ \\
\hline 30 Jul. 98 & $97 \mathrm{c}$ & $109 \mathrm{bc}$ & $102 b c$ & $125 \mathrm{~b}$ & $100 \mathrm{bc}$ & $120 \mathrm{bc}$ & $102 \mathrm{bc}$ & 181 a & $98 \mathrm{bc}$ & $120 b c$ & $107 b c$ & $122 b c$ \\
\hline 07 Aug. 98 & 108 bc & $115 b c$ & 108 bc & $134 \mathrm{~b}$ & $110 b c$ & $121 \mathrm{bc}$ & $108 b c$ & 189 a & $104 \mathrm{c}$ & $126 \mathrm{bc}$ & $107 \mathrm{bc}$ & $126 b c$ \\
\hline 13 Aug. 98 & $83 \mathrm{~cd}$ & 92 bcd & 88 bcd & $107 \mathrm{bc}$ & $80 d$ & 97 bcd & $82 \mathrm{~cd}$ & $171 \mathrm{a}$ & $80 d$ & 95 bcd & $85 \mathrm{~cd}$ & $111 \mathrm{~b}$ \\
\hline 20 Aug. 98 & $71 \mathrm{~b}$ & $79 \mathrm{~b}$ & $75 \mathrm{~b}$ & $91 \mathrm{~b}$ & $69 \mathrm{~b}$ & $82 \mathrm{~b}$ & $70 \mathrm{~b}$ & 148 a & $71 \mathrm{~b}$ & $81 \mathrm{~b}$ & $72 \mathrm{~b}$ & $86 \mathrm{~b}$ \\
\hline 03 Sep. 98 & $57 \mathrm{~b}$ & $60 \mathrm{~b}$ & $59 \mathrm{~b}$ & $66 \mathrm{~b}$ & $54 \mathrm{~b}$ & $58 \mathrm{~b}$ & $53 \mathrm{~b}$ & $109 \mathrm{a}$ & $59 \mathrm{~b}$ & $63 b$ & $56 \mathrm{~b}$ & $66 \mathrm{~b}$ \\
\hline 10 Sep. 98 & $53 \mathrm{~b}$ & $56 \mathrm{~b}$ & $56 \mathrm{~b}$ & $61 \mathrm{~b}$ & $52 \mathrm{~b}$ & $53 \mathrm{~b}$ & $49 b$ & $97 \mathrm{a}$ & $57 \mathrm{~b}$ & $59 \mathrm{~b}$ & $53 \mathrm{~b}$ & $62 b$ \\
\hline 17 Sep. 98 & $50 \mathrm{~b}$ & $54 \mathrm{~b}$ & $54 \mathrm{~b}$ & $57 \mathrm{~b}$ & $49 \mathrm{~b}$ & $50 \mathrm{~b}$ & $47 \mathrm{~b}$ & $86 a$ & $54 \mathrm{~b}$ & $56 \mathrm{~b}$ & $50 \mathrm{~b}$ & $56 \mathrm{~b}$ \\
\hline 24 Sep. 98 & $53 \mathrm{~b}$ & $54 \mathrm{~b}$ & $54 \mathrm{~b}$ & $58 \mathrm{~b}$ & $51 \mathrm{~b}$ & $50 \mathrm{~b}$ & $48 \mathrm{~b}$ & $86 a$ & $58 \mathrm{~b}$ & $57 \mathrm{~b}$ & $49 \mathrm{~b}$ & $57 \mathrm{~b}$ \\
\hline 01 Oct. 98 & $61 \mathrm{~b}$ & $60 \mathrm{~b}$ & $60 b$ & $65 \mathrm{~b}$ & $57 \mathrm{~b}$ & $55 \mathrm{~b}$ & $55 \mathrm{~b}$ & 97 a & $64 \mathrm{~b}$ & $65 \mathrm{~b}$ & $51 \mathrm{~b}$ & $63 b$ \\
\hline 05 Oct. 98 & $59 \mathrm{~b}$ & $59 \mathrm{~b}$ & $58 \mathrm{~b}$ & $63 \mathrm{~b}$ & $56 \mathrm{~b}$ & $54 \mathrm{~b}$ & $54 \mathrm{~b}$ & 94 a & $63 \mathrm{~b}$ & $63 \mathrm{~b}$ & $51 \mathrm{~b}$ & $62 \mathrm{~b}$ \\
\hline 22 Oct. 98 & $75 \mathrm{bc}$ & $68 \mathrm{bc}$ & $68 \mathrm{bc}$ & $73 \mathrm{bc}$ & $78 \mathrm{bc}$ & $58 \mathrm{c}$ & $63 b c$ & $103 a$ & $82 \mathrm{~b}$ & $72 b c$ & $63 \mathrm{bc}$ & $71 \mathrm{bc}$ \\
\hline 30 Oct. 98 & $69 b c$ & $63 b c$ & $65 b c$ & $68 \mathrm{bc}$ & $69 \mathrm{bc}$ & $56 \mathrm{c}$ & $58 \mathrm{c}$ & $95 \mathrm{a}$ & $78 \mathrm{~b}$ & $69 \mathrm{bc}$ & $61 \mathrm{bc}$ & $66 \mathrm{bc}$ \\
\hline 05 Nov. 98 & $72 b c$ & $65 \mathrm{bc}$ & $68 \mathrm{bc}$ & $71 \mathrm{bc}$ & $71 b c$ & $58 \mathrm{c}$ & $61 \mathrm{c}$ & 97 a & $81 a b$ & $72 b c$ & $65 \mathrm{bc}$ & $70 \mathrm{bc}$ \\
\hline
\end{tabular}

Means within the same row followed by the same letter are not different (LS Means test; $\mathrm{P} \leq 0.05$ ); wilting point $=95 \mathrm{~mm}$, field capacity $=155 \mathrm{~mm}$

Table 3. Total soil ( 0 to $50 \mathrm{~cm}$ ) water (mm) for all watersheds $x$ slopes in 1999.

\begin{tabular}{|c|c|c|c|c|c|c|c|c|c|c|c|c|}
\hline \multirow[t]{2}{*}{ Date } & \multicolumn{4}{|c|}{ Very Heavy Grazed } & \multicolumn{4}{|c|}{ Heavy Grazed } & \multicolumn{4}{|c|}{ Control } \\
\hline & Upper & Mid & Low & Coll. & Upper & Mid & Low & Coll. & Upper & Mid & Low & Coll. \\
\hline 24 Mar. 99 & $86 \mathrm{~cd}$ & $88 \mathrm{~cd}$ & $76 d$ & $91 \mathrm{~cd}$ & $91 \mathrm{~cd}$ & $78 \mathrm{~d}$ & $110 \mathrm{abc}$ & $132 \mathrm{a}$ & $108 b c$ & $94 \mathrm{~cd}$ & $122 a b$ & $122 a b$ \\
\hline 14 Apr. 99 & $83 \mathrm{de}$ & 85 cde & $74 \mathrm{e}$ & 87 cde & 95 cde & $77 \mathrm{e}$ & $101 \mathrm{bcd}$ & $125 \mathrm{a}$ & $105 b c$ & $91 \mathrm{c}$ & $120 \mathrm{ab}$ & $115 \mathrm{ab}$ \\
\hline 27 Apr. 99 & $106 \mathrm{c}$ & $108 \mathrm{c}$ & $99 \mathrm{c}$ & $110 \mathrm{c}$ & $116 b c$ & $96 \mathrm{c}$ & $120 b c$ & 149 a & $137 \mathrm{ab}$ & $114 b c$ & $149 \mathrm{a}$ & $149 \mathrm{a}$ \\
\hline 04 May 99 & $108 \mathrm{~cd}$ & $109 \mathrm{~cd}$ & $100 \mathrm{~cd}$ & $111 \mathrm{~cd}$ & $121 b c$ & $97 \mathrm{~d}$ & $121 \mathrm{bc}$ & $150 \mathrm{a}$ & $139 a b$ & $118 b c$ & $148 \mathrm{a}$ & $152 \mathrm{a}$ \\
\hline 13 May 99 & $120 \mathrm{~cd}$ & $120 \mathrm{~cd}$ & $101 \mathrm{~d}$ & $111 \mathrm{~d}$ & $128 \mathrm{bcd}$ & $103 \mathrm{~d}$ & $125 \mathrm{~cd}$ & $150 \mathrm{abc}$ & $150 \mathrm{abc}$ & $126 \mathrm{bcd}$ & $157 \mathrm{ab}$ & $168 \mathrm{a}$ \\
\hline 28 May 99 & $116 \mathrm{~cd}$ & $121 \mathrm{bcd}$ & $99 \mathrm{~d}$ & $111 \mathrm{~cd}$ & $125 \mathrm{bcd}$ & $103 \mathrm{~d}$ & $109 \mathrm{~cd}$ & $146 \mathrm{ab}$ & $147 \mathrm{ab}$ & $136 \mathrm{bc}$ & $146 \mathrm{ab}$ & $164 \mathrm{a}$ \\
\hline 04 Jun. 99 & $172 b c$ & $175 \mathrm{bc}$ & $166 \mathrm{c}$ & $171 \mathrm{bc}$ & $174 b c$ & $167 \mathrm{c}$ & $166 c$ & $195 \mathrm{a}$ & $182 \mathrm{abc}$ & $189 \mathrm{ab}$ & $185 \mathrm{abc}$ & $198 \mathrm{a}$ \\
\hline 11 Jun. 99 & $148 \mathrm{~cd}$ & $155 \mathrm{~cd}$ & $145 \mathrm{~d}$ & $153 \mathrm{~cd}$ & $152 \mathrm{~cd}$ & $148 \mathrm{~cd}$ & $145 \mathrm{~d}$ & $176 a b$ & 160 bcd & $168 \mathrm{abc}$ & $162 \mathrm{abcd}$ & $179 a$ \\
\hline 18 Jun. 99 & $133 \mathrm{~cd}$ & $142 \mathrm{~cd}$ & $131 \mathrm{~cd}$ & $137 \mathrm{~cd}$ & $140 \mathrm{~cd}$ & $139 \mathrm{~cd}$ & $162 a b$ & $126 \mathrm{~d}$ & $144 \mathrm{bcd}$ & $152 \mathrm{abc}$ & $150 \mathrm{abcd}$ & $167 \mathrm{a}$ \\
\hline 23 Jun. 99 & $113 \mathrm{a}$ & $124 \mathrm{a}$ & $118 \mathrm{a}$ & $116 a$ & $143 \mathrm{a}$ & $123 \mathrm{a}$ & $109 a$ & $147 \mathrm{a}$ & $124 \mathrm{a}$ & $131 \mathrm{a}$ & $134 \mathrm{a}$ & 149 a \\
\hline 02 Jul. 99 & $143 \mathrm{bc}$ & $143 b c$ & 144 bc & $143 \mathrm{bc}$ & $143 b c$ & $144 b c$ & $124 \mathrm{c}$ & $171 \mathrm{a}$ & $155 \mathrm{abc}$ & $158 \mathrm{ab}$ & $153 \mathrm{abc}$ & $176 \mathrm{a}$ \\
\hline 13 Jul. 99 & $120 \mathrm{~cd}$ & $125 \mathrm{bcd}$ & $123 \mathrm{~cd}$ & $123 \mathrm{~cd}$ & $121 \mathrm{~cd}$ & $122 \mathrm{~cd}$ & $104 \mathrm{~d}$ & $149 \mathrm{ab}$ & $131 \mathrm{abcd}$ & $133 \mathrm{abc}$ & $132 \mathrm{abcd}$ & $153 \mathrm{a}$ \\
\hline 21 Jul. 99 & 149 a & $134 \mathrm{a}$ & $139 \mathrm{a}$ & $132 \mathrm{a}$ & $135 \mathrm{a}$ & $133 \mathrm{a}$ & $114 \mathrm{a}$ & 165 a & $142 \mathrm{a}$ & $144 \mathrm{a}$ & $140 \mathrm{a}$ & $166 \mathrm{a}$ \\
\hline 12 Aug. 99 & $123 a b c$ & $125 a b c$ & $124 a b c$ & $119 \mathrm{bc}$ & $118 \mathrm{bc}$ & $109 \mathrm{bc}$ & $99 \mathrm{c}$ & $156 \mathrm{a}$ & $144 a b$ & $137 \mathrm{ab}$ & $128 a b c$ & $155 \mathrm{a}$ \\
\hline 18 Aug. 99 & $148 \mathrm{bcd}$ & $151 \mathrm{bcd}$ & $151 \mathrm{bcd}$ & $145 \mathrm{~cd}$ & $138 \mathrm{cde}$ & $135 \mathrm{de}$ & $108 \mathrm{e}$ & $179 \mathrm{ab}$ & $172 a b c$ & $168 \mathrm{abcd}$ & $159 \mathrm{abcd}$ & 189 a \\
\hline 25 Aug. 99 & $124 \mathrm{~cd}$ & $133 \mathrm{bcd}$ & $135 \mathrm{abcd}$ & $125 \mathrm{~cd}$ & $116 \mathrm{~cd}$ & $116 \mathrm{~cd}$ & $103 d$ & $160 \mathrm{ab}$ & $150 \mathrm{abc}$ & $144 \mathrm{abc}$ & $138 \mathrm{abcd}$ & $168 \mathrm{a}$ \\
\hline 01 Sep. 99 & 104 bc & $115 \mathrm{abc}$ & $114 a b c$ & $107 \mathrm{bc}$ & $96 \mathrm{c}$ & $95 \mathrm{c}$ & $94 \mathrm{c}$ & $137 \mathrm{ab}$ & $130 \mathrm{abc}$ & $122 a b c$ & $116 \mathrm{abc}$ & $145 \mathrm{a}$ \\
\hline 08 Sep. 99 & $93 \mathrm{bc}$ & $104 \mathrm{abc}$ & $101 \mathrm{abc}$ & $96 \mathrm{bc}$ & $87 c$ & $84 \mathrm{c}$ & $88 \mathrm{c}$ & $124 \mathrm{ab}$ & $119 a b c$ & $109 \mathrm{abc}$ & $102 a b c$ & $133 \mathrm{a}$ \\
\hline 22 Sep. 99 & $84 \mathrm{bc}$ & $93 a b c$ & $91 \mathrm{abc}$ & $87 \mathrm{bc}$ & $79 c$ & $74 \mathrm{c}$ & $83 \mathrm{bc}$ & $113 \mathrm{a}$ & $110 \mathrm{a}$ & $96 a b$ & 84 bc & $116 \mathrm{a}$ \\
\hline 29 Sep. 99 & $84 \mathrm{a}$ & $91 \mathrm{a}$ & 89 a & $85 a$ & $79 \mathrm{a}$ & $73 a$ & $83 \mathrm{a}$ & $111 \mathrm{a}$ & $107 \mathrm{a}$ & $96 \mathrm{a}$ & $86 a$ & $112 \mathrm{a}$ \\
\hline 06 Oct. 99 & $87 a$ & 92 a & 90 a & $87 a$ & $80 a$ & $74 \mathrm{a}$ & $90 a$ & $113 \mathrm{a}$ & $111 \mathrm{a}$ & $97 \mathrm{a}$ & $88 \mathrm{a}$ & $113 \mathrm{a}$ \\
\hline 14 Oct. 99 & $85 a$ & 91 a & $89 a$ & $85 a$ & $80 a$ & $72 a$ & $87 a$ & $112 \mathrm{a}$ & $109 \mathrm{a}$ & $97 \mathrm{a}$ & $88 a$ & $111 \mathrm{a}$ \\
\hline 20 Oct. 99 & $86 a$ & 90 a & 89 a & $85 a$ & $79 a$ & $72 a$ & $85 a$ & $110 \mathrm{a}$ & $110 \mathrm{a}$ & $95 \mathrm{a}$ & $88 \mathrm{a}$ & $111 \mathrm{a}$ \\
\hline 28 Oct. 99 & $83 b c$ & $90 a b c$ & $87 a b c$ & $84 b c$ & $77 \mathrm{c}$ & $69 c$ & $81 b c$ & 108 a & $106 \mathrm{ab}$ & $93 a b c$ & $88 a b c$ & $108 \mathrm{a}$ \\
\hline 04 Nov. 99 & $85 \mathrm{~cd}$ & $89 \mathrm{bcd}$ & 89 bcd & $84 \mathrm{~d}$ & $79 \mathrm{~d}$ & $72 d$ & $82 d$ & $110 \mathrm{ab}$ & $109 \mathrm{abc}$ & 95 abcd & 89 bcd & $113 \mathrm{a}$ \\
\hline 18 Nov. 99 & $87 c$ & $91 \mathrm{bc}$ & $90 \mathrm{c}$ & $86 c$ & $84 \mathrm{c}$ & $74 \mathrm{c}$ & $83 \mathrm{c}$ & $114 \mathrm{ab}$ & $118 \mathrm{a}$ & $99 \mathrm{abc}$ & $99 \mathrm{abc}$ & $117 \mathrm{a}$ \\
\hline
\end{tabular}

Means within the same row followed by the same letter are not different (LS Means test; $P \leq 0.05$ ); wilting point $=95 \mathrm{~mm}$, field capacity $=155 \mathrm{~mm}$ 

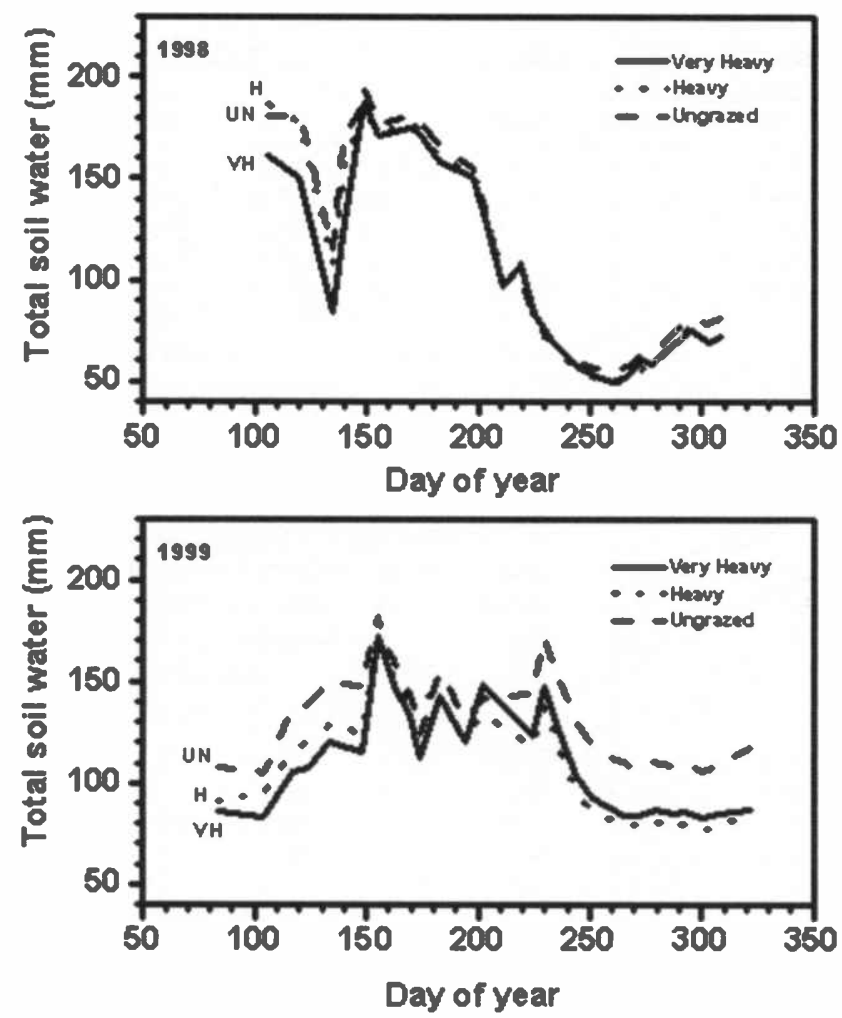

Fig. 1. Total soil water $(\mathrm{mm})$ at depth interval of $0-50 \mathrm{~cm}$ for the upper-slope positions in 1998 and 1999 for very heavy grazed, heavy grazed and ungrazed treatments.
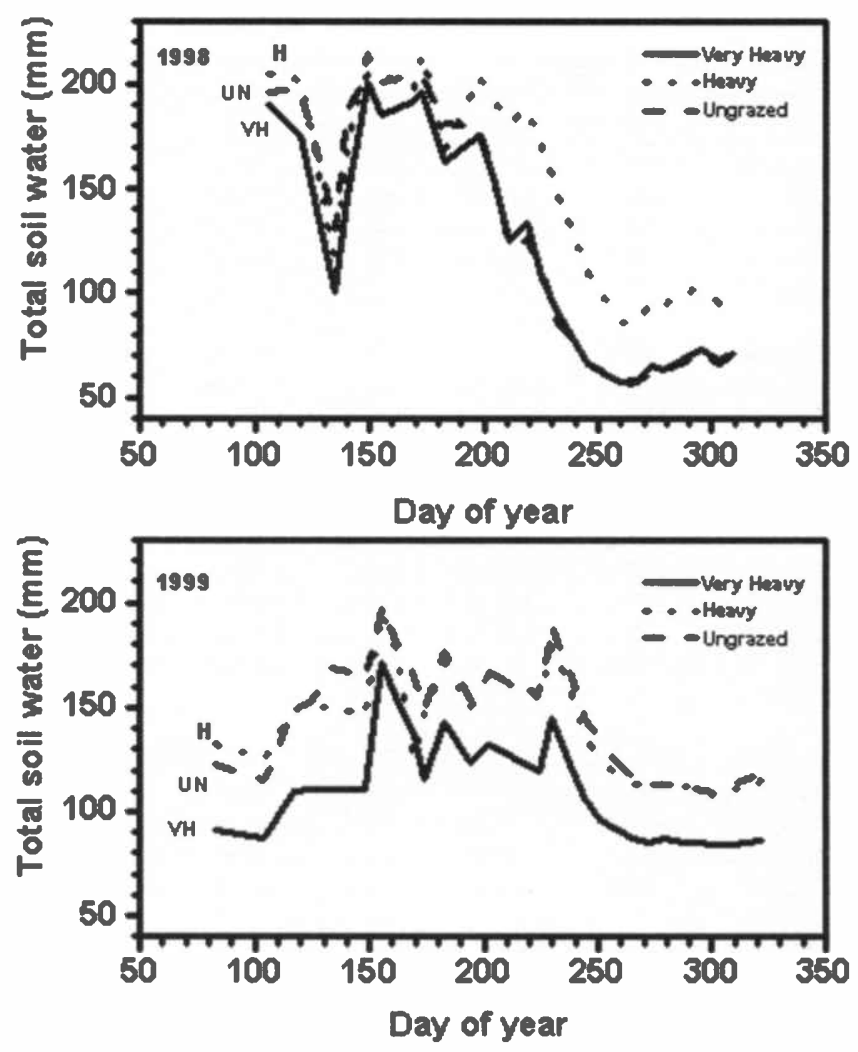

Fig. 2. Total soil water $(\mathrm{mm})$ at depth interval of $0-50 \mathrm{~cm}$ for the collector drain positions in 1998 and 1999 for very heavy grazed, heavy grazed and ungrazed treatments .

\section{Comparison of total soil water to FC and WP}

In both 1998 and 1999, more than $50 \%$ of total soil water measurements were $>$ wilting point (WP), with some even $>$ field capacity (FC) (Table 4). There was little difference in the frequency of soil water occurrences between the 2 grazing treatments: in both years soil water was most frequently in Class I (Table 4), espe- cially in 1999, but with some in Class VI (very wet) only in 1998. The ungrazed control treatment had soil water frequencies similar to those of the grazed treatments in 1998. The lack of significant differences in soil water among slope positions is clearly evident in the soil water frequency data (Table 4). The collector position did show some differences from the other 3 positions, notably for the heavy grazed watershed for both years and for the control in 1999. Interestingly the differences for the very heavy grazed watershed were minor for both years.

The average end-of-season values (late October) across all treatments and watersheds was $68(10) \mathrm{mm}$ and $90(12) \mathrm{mm}$, for 1998 and 1999, respectively, with numbers in brackets being standard deviation. End-of-season soil water was near or

Table 4. Soil water frequency and cumulative frequency for the 3 watersheds at 4 slope positions.

\begin{tabular}{|c|c|c|c|c|c|c|c|c|c|c|c|c|c|}
\hline \multirow[t]{2}{*}{ Class } & \multirow[t]{2}{*}{ TSW50* } & \multicolumn{4}{|c|}{ Very Heavy Grazed } & \multicolumn{4}{|c|}{ Heavy Grazed } & \multicolumn{4}{|c|}{ Control } \\
\hline & & Upper & Mid & Low & Coll. & Upper & Mid & Low & Coll. & Upper & Mid & Low & Coll. \\
\hline I & $<95$ & 12 & 11 & 12 & 10 & 11 & 11 & 12 & 3 & 11 & 10 & 11 & 10 \\
\hline II & $95-109$ & 2 & 2 & 2 & 2 & 2 & 1 & 2 & 6 & 2 & 1 & 2 & 0 \\
\hline III & $110-124$ & 0 & 1 & 0 & 0 & 1 & 2 & 0 & 1 & 1 & 2 & 1 & 1 \\
\hline IV & $125-139$ & 2 & 0 & 2 & 2 & 1 & 1 & 2 & 0 & 1 & 1 & 1 & 2 \\
\hline V & $140-155$ & 2 & 2 & 2 & 1 & 1 & 1 & 0 & 1 & 1 & 1 & 1 & 0 \\
\hline VI & $>155$ & 7 & 9 & 7 & 10 & 9 & 9 & 9 & 14 & 9 & 10 & 10 & 11 \\
\hline I & $<95$ & 11 & 10 & 10 & 10 & 10 & 11 & 10 & 0 & 0 & 3 & 7 & 0 \\
\hline II & $95-109$ & 3 & 3 & 5 & 2 & 2 & 6 & 7 & 1 & 6 & 8 & 2 & 1 \\
\hline III & $110-124$ & 6 & 4 & 4 & 4 & 5 & 3 & 3 & 8 & 6 & 3 & 3 & 9 \\
\hline IV & $125-139$ & 1 & 4 & 3 & 3 & 4 & 3 & 3 & 4 & 4 & 4 & 4 & 1 \\
\hline V & $140-155$ & 4 & 3 & 3 & 3 & 4 & 2 & 2 & 6 & 7 & 2 & 6 & 5 \\
\hline VI & $>155$ & 1 & 2 & 2 & 1 & 1 & 1 & 2 & 7 & 3 & 4 & 4 & 10 \\
\hline
\end{tabular}

*TSW50 = Total soil water $(\mathrm{mm})$ to a depth of $50 \mathrm{~cm} . \mathrm{U}=$ upper slope, $\mathrm{M}=$ middle slope, $\mathrm{L}=$ lower slope, $\mathrm{C}=$ close to collector drain. 

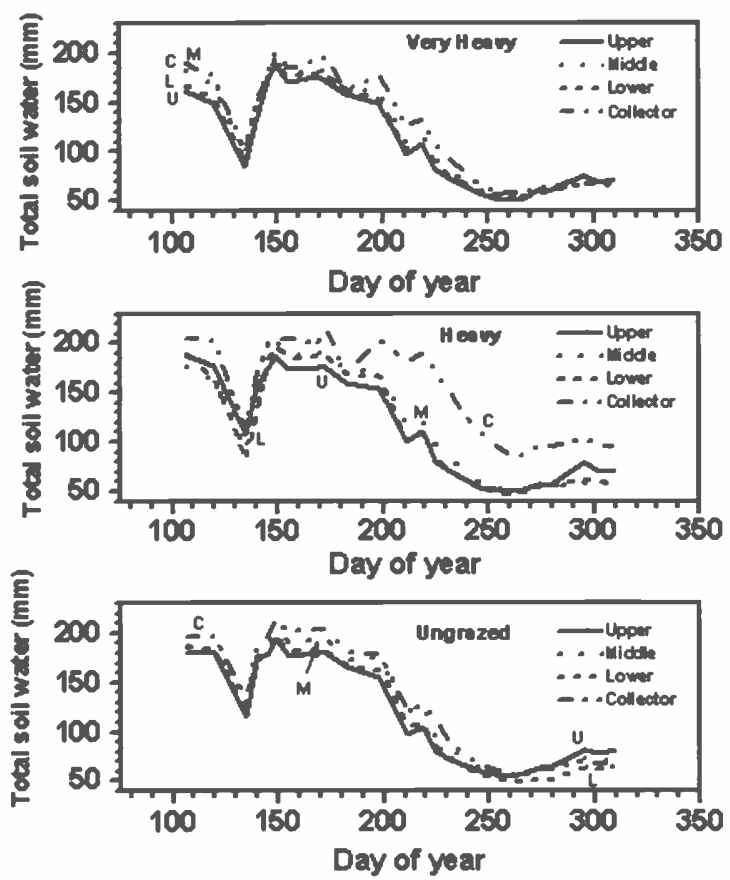

Fig. 3. Total soil water $(\mathrm{mm})$ at depth interval of $0-50 \mathrm{~cm}$ for the 4 slope positions in 1998 under very heavy grazed, heavy grazed and ungrazed treatments.

less than wilting point in all watersheds in both years (Tables 2 and 3), regardless of the amount of growing season precipitation, indicating that the plants use as much water as is available to them. That soil water was often below wilting point may not be of biological significance since the wilting point is species dependent and

many grassland species have a lower wilting point than agronomic species. This implies that they can survive in arid grassland ecosystems, where range grasses have been reported to have wilting points ranging between -800 and $-3860 \mathrm{kPa}$ (Naeth 1988). The data may also indicate that the laboratory-determined value of FC at $-33 \mathrm{kPa}$ may be too conservative for the field conditions. Normally WP soil moisture contents change little at suctions < $-1500 \mathrm{MPa}$, so the laboratory-determined soil moisture values of WP may be acceptable. In reality, vegetative adaptations to drought become the major issue at very low soil moisture contents.

The 2 study years provided a wide range of soil water conditions for evaluation (Table 4). In 1998 frequency of soil water occurrences was bimodal, with many values in Class I (<WP) and many in Class VI (> FC) for all treatments. In 1999 soil water was distributed among all classes throughout the year.

Confidence in the true soil water patterns of these watersheds having been determined is high, given the large number of measurement dates. For each study year, the lack of significant differences in soil water among slope positions (Tables 2 and 3) may have been due to the rather uniform slopes within the watersheds.

\section{Model Performance}

Model performance in simulating volumetric soil water content in 1998 was generally fair. Table 5 summarizes the 6 statistics given by equations 1-6, calculated for volumetric soil water content for each soil depth and for the 3 watersheds in 1998. The discrepancy between predicted and observed values of volumetric soil water was small and both the coefficient of residual mass (CRM) and coefficient of determination (CD) values indicated that

Table 5. Model performance statistics for volumetric soil water data predicted with VB2000 at 3 watersheds in 1998.

\begin{tabular}{|c|c|c|c|c|c|c|c|}
\hline Watershed & $\begin{array}{l}\text { Soil depth } \\
\text { grazing }\end{array}$ & \multicolumn{5}{|c|}{ Statistic $^{I}$} & $\mathrm{CD}$ \\
\hline & $(\mathrm{cm})$ & & & & & & \\
\hline \multirow[t]{6}{*}{ Control } & 15 & 0.65 & 40.8 & 1101 & -0.024 & 0.21 & 14.0 \\
\hline & 25 & -2.06 & 29.7 & 790 & 0.078 & 0.50 & 3.3 \\
\hline & 35 & -2.89 & 24.3 & 623 & 0.112 & 0.60 & 2.4 \\
\hline & 45 & -1.17 & 18.9 & 492 & 0.045 & 0.68 & 1.8 \\
\hline & 55 & -1.76 & 18.1 & 512 & 0.063 & 0.65 & 1.5 \\
\hline & All depths & -1.44 & 10.0 & 267 & 0.054 & 0.53 & 3.0 \\
\hline \multirow[t]{6}{*}{ Heavy } & 15 & 3.29 & 41.3 & 1144 & -0.119 & 0.05 & 7.6 \\
\hline & 25 & -3.36 & 31.3 & 845 & 0.125 & 0.29 & 2.8 \\
\hline & 35 & -0.25 & 18.1 & 487 & 0.009 & 0.68 & 1.7 \\
\hline & 45 & -2.95 & 18.6 & 510 & 0.108 & 0.47 & 0.9 \\
\hline & 55 & -2.59 & 17.1 & 518 & 0.086 & 0.29 & 0.6 \\
\hline & All depths & -1.17 & 9.7 & 270 & 0.042 & 0.45 & 1.9 \\
\hline \multirow[t]{7}{*}{ Very heavy } & 15 & 3.79 & 44.7 & 1139 & -0.149 & 0.08 & 6.2 \\
\hline & 25 & -3.77 & 33.4 & 822 & 0.154 & 0.32 & 2.4 \\
\hline & 35 & -1.97 & 22.4 & 544 & 0.081 & 0.62 & 1.9 \\
\hline & 45 & 0.14 & 17.2 & 370 & 0.136 & 0.70 & 1.2 \\
\hline & 55 & 0.77 & 16.8 & 471 & -0.027 & 0.53 & 0.8 \\
\hline & All depths & -0.21 & 10.4 & 264 & 0.008 & 0.41 & 1.8 \\
\hline & Whole year & -0.94 & 17.3 & 463 & 0.035 & 0.47 & \\
\hline
\end{tabular}

If all predicted and observed values were the same, the statistics above would have values of: $A E=0.0 ; R M S E=0.0$;

$\mathrm{RMS}=0.0 ; \mathrm{CRM}=0.0, \mathrm{EF}=1.0$ and $\mathrm{CD}=1.0$ 


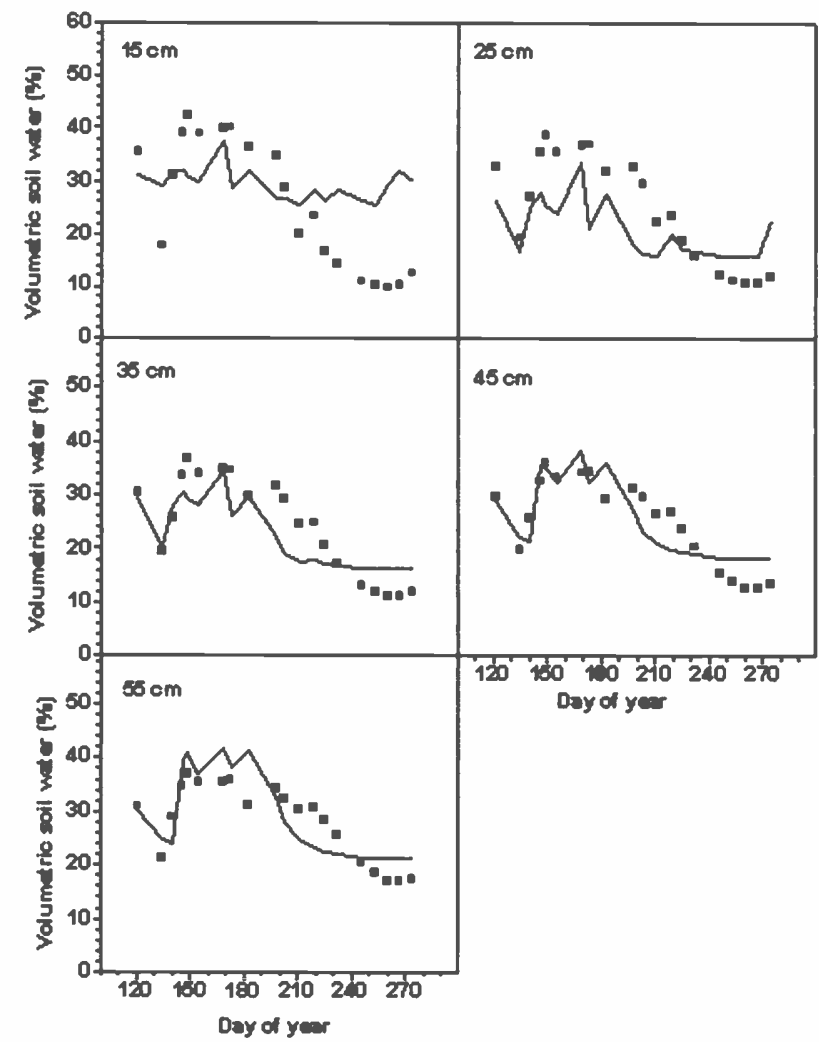

Fig. 4. Volumetric soil water measured (squares) and simulated (solid line) using VB2000 model for the very heavy grazed watershed in 1998.

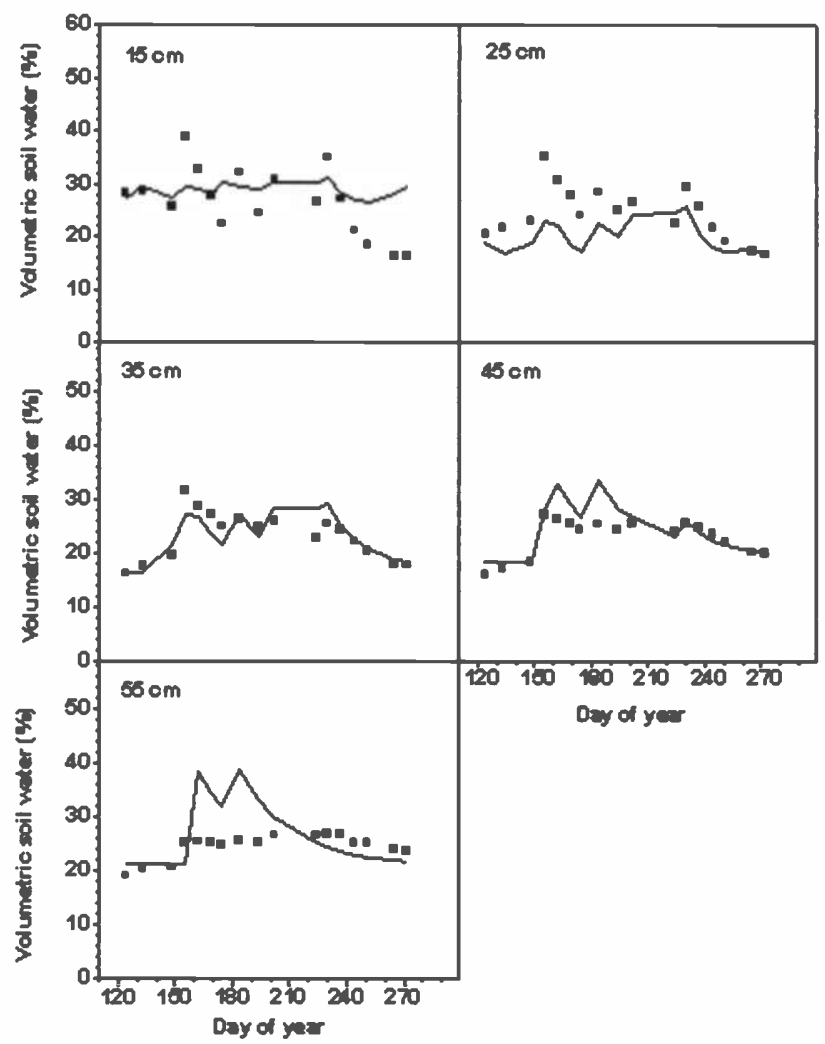

Fig. 5. Volumetric soil water measured (squares) and simulated (solid line) using VB2000 model for the very heavy grazed watershed in 1999. for all watersheds and for most soil depths, the model slightly under-estimated the volumetric soil water content (Table 5). However, the model prediction at 15 $\mathrm{cm}$ was an exception, with the model slightly over-estimating the volumetric soil water for all 3 watersheds. This is also evident in the plot of simulated and observed values over the growing season, which showed substantial variation among soil depths (Fig. 4). Graphical depictions are presented for only the very heavy grazed treatment; generally representative of the trends in the other 2 treatments. The overall model performance for all 3 watersheds in 1998 indicated that the model slightly under-predicted the volumetric soil water content $(\mathrm{CRM}=0.035 ; \mathrm{EF}=$ 0.47).

Model predictions for 1999 volumetric soil water had a similar pattern to that in 1998. For all 3 watersheds and for most soil depths, the model generally over-estimated the volumetric soil water content. However, at the $25-\mathrm{cm}$ soil depth, the model under-estimated the volumetric soil water content in all 3 watersheds. The overall model performance against 1999 data indicated a small average error and slight over-prediction $(\mathrm{CRM}=0.038)$, but the modeling efficiency was not good (EF $=0.30$ ). Plots of volumetric soil water content at various depths indicate less fluctuation at greater depths over the growing season (Fig. 5).

Finally, considering all the data for all watersheds, all depths and all years combined, the average error was approximately $5 \%$ volumetric soil water (absolute), and the model slightly overestimated soil water content $(C R M=-0.08)$. However, the model efficiency $(E F=0.19)$ was very low. Generally, the model predictions could be considered satisfactory given that no attempts were made to calibrate the model.

The discrepancies between model results and observed data may be partly due to the spatial variation in volumetric soil water among slope positions and also due to presence of rocks or cracks, which could influence soil water dynamics. Soil water was slightly affected by slope position such that the averaging across slopes for each watershed may have contributed to the discrepancy between model results and observed data. Also, the model does not take into account these factors and the use of water uptake coefficients may also have contributed to the discrepancies, since the root distribution pattern assumed may not be exact. The conservative approach to drainage (need to reach field capacity before drainage occurs) may also have partly accounted for the over-estimation of soil water using Versatile Soil Moisture Budget model (VB2000).

\section{Conclusions}

In both 1998 and 1999, grazing treatments did not affect the total soil water for the 0-50 cm interval (TSW50) in upper, middle and lower slope positions, but close to the collector drain the very heavy grazed treatment had significantly lower TSW50 than the ungrazed treatment. Within each grazing treatment TSW50 among slope positions was significantly different mostly for the heavy grazed treatment and for some measurement dates under the ungrazed treatment. Grazed treatments had lower TSW50 than the ungrazed treatment possibly because of reduced infiltration and recharge of soil profile. The high precipitation in 1998 compared with 1999 resulted in total soil water greater than laboratory-determined 
field capacity on some days. In both 1998 and 1999 , more than $50 \%$ of total soil water measurements were greater than wilting point. In the heavy grazed and ungrazed watersheds, soil water frequencies in classes II and VI were much greater at the collector position compared with other slope positions.

The simulation of soil water content using the VB2000 model yielded variable results among watersheds and years. The overall model simulation was better for the 1999 data compared to other years. However, for both years the model generally under-predicted soil moisture. Simulations of soil moisture at 35- and 45$\mathrm{cm}$ depths were closest to measured values with modeling efficiency up to $70 \%$. The overall performance of the model indicated an over-prediction of the soil water content for the watersheds studied. Overall the model has potential for further use in grazed watersheds, although data such as permanent wilting point for grass species and crop coefficients that are appropriate for each grazing treatment would be essential to achieve meaningful simulations.

\section{Literature Cited}

Baier, W. and G.W. Robertson. 1966. Estimation of latent heat evaporation from simple weather observations. Can. J. Plant Sci.45:276-284.

Baier, W. and G.W. Robertson. 1996. Soil moisture modelling - conception and evolution of the VSMB. Can J. Soil Sci. 76:251-261.

Baier, W., J.B. Boisvert, and J.A. Dyer. 2000. The versatile soil moisture budget (VB) reference manual. ECORC Contribution Number 001553.

Brye, K.R., J.M. Norman, L.G. Bundy, and S.T. Gower. 2000. Water-budget evaluation of prairie and maize ecosystems. Soil Sci. Soc. Am. J. 64:715-724.

Burk, A.R., D.S. Chanasyk, and E. Mapfumo. 2000. Antecedent soil water for managed landscapes in Central Alberta. Trans. Amer. Soc. Agr. Eng. 43:1467-1475.

Chanasyk D.S., Mapfumo E., and Willms, W.D. 2003. Quantification and simulation of surface runoff from fescue grassland watersheds. Agric. Water Manage. 59:137-153.

Elmaloglou, St. and N. Malamos. 2000. Simulation of soil moisture content of a prairie field with SWAP93. Agr. Water Manage. 43:39-149.

Hymer, D.C., M.S. Moran, and T.O. Keefer. 2000. Soil water evaluation using a hydrological model and calibrated sensor network. Soil Sci. Soc. Amer. J. 64:319-326.
Loague, K. and R.E. Green. 1991. Statistical and graphical methods for evaluating solute transport models: Overview and application. J. Contam. Hydrol. 7:51-73.

Monteith, J.L. 1980. The development and extension of Penman's evaporation formula, p. 247-253, In: D. Hillel, Applications of soil physics. Academic Press, New York.

Naeth, M.A. 1988. The impact of grazing on litter and hydrology in mixed prairie and fescue grassland ecosystems of Alberta. Ph.D. Dissertation, Department of Plant Science, University of Alberta, Edmonton, Alberta. 173 pp.

Naeth, M.A. and D.S. Chanasyk. 1995. Grazing effects on soil water in Alberta foothills fescue grasslands. J. Range Manage. 48:528-534.

Naeth, M.A. and D.S. Chanasyk. 1996. Runoff and sediment yield under grazing in foothills fescue grasslands of Alberta. J. Amer. Water Resour. Assoc. 32:89-95.

Naeth, M.A., D.S. Chanasyk, R.L. Rothwell and A.W. Bailey. 1991. Grazing impacts on soil water in mixed prairie and fescue grassland ecosystems of Alberta. Can. J. Soil Sci. 71: 313-325.

SAS Institute 2000. SAS/STAT user's guide Version 8.1. SAS Institute, Cary, N.C.

Twerdoff, D.A., D.S. Chanasyk, M.A. Naeth, V.S. Baron and E. Mapfumo. 1999. Soil water regimes of rotationally grazed perennial and annual forages. Can. J. Soil Sci. 79: $627-637$. 